\title{
PATENTS AND PLANT BREEDER'S RIGHTS OVER PLANT GENETIC RESOURCES FOR FOOD AND AGRICULTURE
}

\author{
Charles Lawson ${ }^{*}$
}

\section{INTRODUCTION}

Recognising the importance of species diversity in conserving and exploiting plant genetic resources for food and agriculture, international and domestic arrangements have attempted over the decades in situ conservation, ex situ germplasm collections and germplasm exchange mechanisms. ${ }^{1}$ These initiatives established valuable resources for the development of new crop and forage plant varieties but there were no uniform or binding arrangements for conserving and accessing these resources. A more formal and uniform arrangement to both facilitate the conservation and exchange of some crop and forage plant genetic materials and share the benefits is now addressed in the International Treaty on Plant Genetic Resources for Food and Agriculture ('PGRFA Treaty'). ${ }^{2}$ The Food and Agriculture Organization of the United Nations

* Charles Lawson, Australian Centre for Intellectual Property in Agriculture, School of Law, Griffith University, Nathan OLD. While I accept all responsibility for this work, I appreciate the guidance and suggestions from the anonymous referees. This work was supported by an Australian Research Council grant to research 'Gene Patents in Australia: Options for Reform'.

1 For a summary of these measures see Conference of the Parties to the Convention on Biological Diversity, Progress Under the FAO Global System for the Conservation and Sustainable Utilization of Plant Genetic Resources for Food and Agriculture, UNEP/CBD/COP/3/15 (1996); Conference of the Parties to the Convention on Biological Diversity, FAO Global System for Plant Genetic Resources for Food and Agriculture, UNEP/CBD/COP/2/18 (1995).

2 Opened for signature 3 November 2001, [2002] ATNIF 14 (not yet in force); '[t]he Govemment proposes to deposit Australia's instrument of ratification as soon as practicable after the end of the tabling period': Intemational Treaty on Plant Gentetic Resources for Food and Agriculture, National Interest Analysis (2002) [4] (tabled in the House of Representatives on 3 December 2002); although note that the Parliament's response has not yet been finalised: 'The committee has informed the Minister for Foreign Affairs and the Minister for Agriculture, Fisheries and Forestry that additional time is required beyond the usual 20 sitting day period to consider the proposed treaty action. The additional time will allow the committee to consider concerns raised by key industry stakeholders, such as the Grains Council and Seed Industry Association of Australia, on the detailed financial, technical and policy implications of ratifying the [PGRFA T] reaty': Commonwealth, Parliamentary Debates, House of Representatives, 25 March 2003, 13474 (Julie Bishop MP). 
('FAO') adopted the PGRFA Treaty in 2001, although it has not yet entered into force. ${ }^{3}$ A separate and distinct PGRFA Treaty was the culmination of the re-negotiation of the United Nations' International Undertaking on Plant Genetic Resources for Food and Agriculture 4 recognising 'the special nature of agricultural biodiversity, its distinctive features and problems needing distinctive solutions'.

The PGRFA Treaty followed other related legally binding international agreements dealing with plant genetic materials generally and the various rights to access these materials and importantly, the protection of potential intellectual property rights over those materials. ${ }^{6}$ These agreements include:

(a) The United Nations' Convention on Biological Diversity ('CBD') establishing, in part, a scheme for the conservation of biological diversity, its sustainable use and the fair and equitable sharing of the benefits arising out of the utilization of genetic resources, including by appropriate access to genetic resources and respect for intellectual property rights; ${ }^{9}$ and

Adoption of the International Treaty on Plant Genetic Resources for Food and Agriculture and Interim Arrangements for its Implementation, Res 3, UN FAO, 31 st sess, conf (2001); see also Conference of the United Nations Food and Agriculture Organization, International Undertaking on Plant Genetic Resources for Food and Agriculture, C 2001/16 (2001); the PGRFA Treaty enters into force after the fortieth instrument of ratification, acceptance, approval or accession is deposited, at least twenty being from FAO members (art 28(1)); countries have agreed to continue inviting ratification: see, eg, 'Plan of Implementation of the World Summit on Sustainable Development', UN Report of the World Summit on Sustainable Deoelopment (2002) 6, 31 [40q].

4 Intemational Undertaking on Plant Genetic Resources, Res 8, UN FAO, 22nd sess, conf (1983); agreed interpretations were subsequently adopted in 1989 (Agreed Interpretation of the International Undertaking Res 4, UN FAO, 25 th sess, conf (1989) and Farmer's Rights, Res 5 , International Undertaking, Res 49) and in 1991 (Res 3, UN FAO, 26 th sess, conf (1991)) and annexed to the Undertaking.

5 Conference of the Parties to the Convention on Biological Diversity, FAO Global System for the Conservation and Utilization of Plant Genetic Resources for Food and Agriculture, Decision II $/ 15$, UNEP/CBD/COP/2/19 (1995) 26.

6 A useful statement of the applicable laws and policy issues relating to agriculture and under consideration in international fora are discussed in Michael Blakeney, 'Access to under consideration in internationas Inventions and Agriculture' (Study Paper No 3b, Genetic Resources, Gene-Based Inventions, and Agriculture' (Stud, Access to Genetic Resources, Gene-Based Inventions and Agriculture' (Study Paper No 3a, Commission on Intellectual Property Rights, 2002).

7 Opened for signature 5 June 1992, [1993] ATS 32 (entered into force generally and for Australia on 29 December 1993).

8 Biological diversity may be considered at three levels, genetic diversity, species diversity and ecosystem diversity: see Commonwealth Department of the Environment, Sport and Territories, National Strategy for the Conservation of Australia's Biological Diversity (1996) 1.

9 Aspects of the CBD are included in domestic Australian legislation as the Environment Protection and Biodiversity Conseroation Act 1999 (Cth), with access to genetic resources addressed in s 301; although there are a number of other laws that affect various other aspects of access: see, eg, Wildlife Protection (Regulation of Exports and Imports) Act 1982 (Cth), Customs (Prohibited Exports) Regulations 1958 (Cth). 
The World Trade Organization's ('WTO') Agreement on Trade-Related Aspects of Intellectual Property Rights ('TRIPS') ${ }^{10}$ setting, in part, minimum standards for patents and a sui generis scheme for plant inventions, now reflected in domestic Australian legislation as 'exclusive rights' under the Patents Act 1990 (Cth) ('Patents Act') ${ }^{11}$ and the Plant Breeder's Rights Act 1994 (Cth) ('Plant Breeder's Rights Act'). ${ }^{12}$

The place of intellectual property rights is central to economic theory about allocating the scarce resources necessary to both conserve and efficiently exploit plant genetic resources for food and agriculture, ${ }^{13}$ with an assumption of overall economic benefit while at the same time having minimal social costs. ${ }^{14}$ Theoretically these intellectual property rights compensate for the disincentive to innovate with a limited

10 Marrakesh Agreement Establishing the World Trade Organisation [1995] ATS 8, Annex 1C (entered into force generally and for Australia 1 January 1995).

11 The Patents (World Trade Organization Amendments) Act 1994 (Cth) amended the Patents Act 1990 (Cth) to be consistent with TRIPS by extending the patent term to 20 years, onus requirements for infringement proceedings, compulsory licenses and Commonwealth and State use of a patent; the statutory 'exclusive rights' under the Patents Act are, 'during the term of the patent, to exploit the invention and to authorise another person to exploit the invention' (Patents Act 1990 (Cth) s 13(1)); these rights are 'personal property' that is 'capable of assignment and of devolution by law' (Patents Act 1990 (Cth) s 13(2)); the term 'exploit', 'in relation to an invention, includes: (a) where the invention is a product - make, hire, sell or otherwise dispose of the product, offer to make, sell, hire or otherwise dispose of it, use or import it, or keep it for the purpose of doing any of those things; or (b) where the invention is a method or process - use the method or process or do any act mentioned in paragraph (a) in respect of a product resulting from such use': Patents Act 1990 (Cth) sch 1.

12 The Plant Breeder's Rights Act 1994 (Cth) implements the Intermational Convention for the Protection of New Varieties of Plants, opened for signature 19 March 1991, [2000] ATS 6 (entered into force generally 24 April 1998 and for Australia 20 January 2000) (based on 2 December 1961 agreement, as revised 10 November 1972 and 23 October 1978); the statutory 'exclusive rights' under the Plant Breeder's Rights Act 1994 (Cth) are 'to do, or to license another person to do, the following acts in relation to propagating material of the variety: (a) produce or reproduce the material; (b) condition the material for the purpose of propagation; (c) offer the material for sale; (d) sell the material; (e) import the material; (f) export the material; $(g)$ stock the material for the purposes described in paragraph (a), (b), (c), (d), (e) or (f)' (s 11), except private and non-commercial purpose acts (s 16(a)), experimental purposes (s 16(b)), the breeding of other plant varieties (s 16(c)) and conditioning for 'reproductive purposes' or reproduction (such as farm saved seeds): $s$ it.

13 This is an ongoing debate between at least two different views about the benefits of intellectual property rights: one view emphasises the need for more intellectual property rights to encourage more innovation, and the contrary 'monopoly distortions' view emphasises the costs of intellectual property rights as extracting too high a cost through monopoly distortion in the market; see generally Peter Drahos with John Braithwaite, Information Feudalism: Who Owns the Knowledge Economy? (2002); Christopher May, A Global Political Economy of Intellectual Property Rights: The New Enclosures (2000); Jay Kesan 'Intellectual Property Protection and Agricultural Biotechnology: A Multidisciplinary Perspective' (2000) 44 American Behavioural Scientist 464.

14 The social costs are higher prices, restricted outputs, subsidised foreign inventors and the administrative costs of the schemes: see, eg, Industrial Property Advisory Committee, Patents, Innooation and Competition in Australia: A Report to the Hon Barry O Jones MP Minister for Science and Technology (1984) 13. 
period of exclusivity that enables the innovator to recover the development costs (confounding the free riders) ${ }^{15}$ This compensation therefore encourages other beneficial innovation through investment in new developments (with the added benefit of disclosure of the innovation). ${ }^{16}$ Given that the conservation and exploitation of plant genetic resources for food and agriculture are vital to Australia's agricultural and environmental circumstances ${ }^{17}$ (and ensuring future global food security), 18 intellectual property rights arguably address a possible market failure and procure the investment necessary to conserve, exploit and generate the new and improved plant genetic resources for food and agriculture. 19 However, the interaction between the PGRFA Treaty, the CBD and TRIPS as they apply to the plant genetic resources for food and agriculture, and the role of intellectual property rights in and between these schemes remains unsettled.

This paper sets out to examine the consequences for Australia's agricultural policy settings for intellectual property arrangements over plant genetic resources for food and agriculture under the PGRFA Treaty and the CBD. This involves examining the conflict between accessing plant genetic resources for food and agriculture (predominantly germplasm) for crop and forage plant improvement and meeting the policy objectives of intellectual property laws to promote innovation and economically useful investment that privately appropriates these resources. The international schemes for access to genetic resources and intellectual property rights set out in the PGRFA Treaty, the CBD and TRIPS, provide a complicated patchwork for domestic policy makers. In domestic Australian laws these international arrangements are reflected in patents under the Patents Act and plant breeder's rights ('PBR') under the Plant Breeder's Rights Act, and the consequences of these statutory rights schemes in setting agricultural policy that satisfies Australia's commercial and environmental circumstances, as well as meeting its obligations under the PGRFA Treaty, the CBD and TRIPS.

The paper is structured as follows:

15 Such as, 'the uncertainty of payoff from $\mathrm{R} \& \mathrm{D}$ and innovative activity' and 'the limited ability of the inventor/innovator to appropriate profits arising from the use of the new knowledge generated': see ibid 12; Bureau of Industry Economics, 'The Economics of Patents' (Occasional Paper No 18, 1994) 13.

16 Trade Practices Commission, Application of the Trade Practices Act to Intellectual Property (1991) 8. for a review of the policy objectives of patenting see Thomas McCarthy, 'Intellectual Property and Trade Practices Policy: Coexistence or Conflict? The American 'Intellectual Property and Trade Practices Polience' (1985) 13 Australian Business Law Reoiew 198, 200-3.

17 This is a regularly expressed contention; see for a recent topical example National Interest Analysis, above n 2, [5]-[8] (tabled in the House of Representatives on 3 December 2002): Australian food and agriculture sectors depend almost entirely on access to overseas sources for [plant genetic resources for food and agriculture] for continued plant improvement and development $t^{t}$ at [7].

18 To meet the demands of an estimated two billion more humans by 2020 and the increasing demands of enlarging populations of urbanised and wealthy consumers - there appears to be a consensus in the literature with numerous commentary on these points; see, eg, Lloyd Evans, Feeding the Ten Billion: Plants and Population Growth (1998).

19 For a recent articulation of this viewpoint that asserts and assumes public benefits see Organisation for Economic Co-operation and Development, Genetic Inventions, Intellectual Property Rights and Licensing Practices: Evidence And Policies (2002) 19. 
Part 2 outlines the PGRFA Treaty establishing a legally binding agreement for the conservation and exchange of certain listed plant genetic resources for food and agriculture through a Multilateral System of 'facilitated access'. In essence, the plant genetic resources for food and agriculture forming the Multilateral System under the PGRFA Treaty are accessible to Contracting Parties under standard materials transfer agreements ('MTAs') subject to a number of mandatory conditions, including the restriction that any patents and $\mathrm{PBRs}$ cannot be claimed over materials accessed from the Multilateral System while it remains 'in the form received from the Multilateral System: ${ }^{20}$ In the negotiation of the intellectual property provisions in the PGRFA Treaty Australia's stance was that it be able to continue to exercise its existing intellectual property rights in accordance with domestic and international law, and in particular the claiming of intellectual property rights over any genetic material 'which meets relevant standards' 21 consistent with the minimum standards required by TRIPS. The likely consequence of this stance in Australia is that materials that cease to be 'in the form received from the Multilateral System' and that were originally accessed from the Multilateral System will be privately appropriated and removed from the Multilateral System through patents and PBRs. Related materials may also be appropriated as a consequence of patenting practices that allow broader claims than just the 'invented' materials;

Part 3 reviews the likely interaction between TRIPS and the CBD's scheme for access to plant genetic resources for food and agriculture and benefit-sharing. This remains a significant interaction until the PGRFA Treaty enters into force. The CBD currently applies to all dealings with plant genetic resources for food and agriculture and will continue to apply to all other plant genetic resources for food and agriculture that have not been included in the PGRFA Treaty's Multilateral System. These analyses find that the CBD is likely to apply subject to the minimum standards required by TRIPS so that countries seeking the fair and equitable sharing of the benefits arising out of the use of their genetic resources will be required to respect minimum intellectual property standards. Again, the likely consequence for Australia is the private appropriation of the plant genetic resources for food and agriculture;

Part 4 contends that the future technological solutions in Australia's agricultural landscape will include both classical breeding techniques and the applications of modern genetic techniques. Both these technological approaches require access to plant genetic resources for food and agriculture that will be sourced primarily from existing ex situ collections, in situ crop and forage plants predominantly maintained by farmers in developing countries, and the wild relatives of domesticated plants. Intellectual property rights are likely to have a significant role in the ways these resources are exploited and conserved. The most important difference being patents privately appropriate plant genetic resources for food and agriculture for the term of the patent, while PBR provides a more limited appropriation and expressly allows the resource to be used to develop new varieties. This presents a dilemma for Australia's policy makers, as Australia's agricultural landscape requires access to these plant genetic resources for food and agriculture. Patents are likely to further confound Australia's agricultural landscape through the need for complex negotiation with private rights

$\overline{20}$ PGRFA Treaty, opened for signature 3 November 2001, [2002] ATNIF 14, art 12(3)(d) (not

yet in force); see further below, text accompanying $n n$ 33-4.

21 See below, text accompanying $n 39$. 
holders to access essential patented products and processes and the potentially adverse consequences of market concentration in particular agricultural sectors. Significantly, these patents are held predominantly by non-residents that in most circumstances will have an interest in avoiding competition in their domestic and foreign markets from Australian products. These patents and PBRs are also likely to undermine the objectives of the PGRFA Treaty, which seeks to provide 'facilitated access' to its Multilateral System, and the incentive for those holding valuable plant genetic resources for food and agriculture to contribute them to the Multilateral System. With an ineffective PGRFA Treaty, through a depletion of its useful materials, a failure of Contracting Parties to contribute materials to the Multilateral System or a failure to enter into force, the CBD scheme is likely to be the default scheme requiring the more onerous process of mutually agreed terms, prior informed consent and so on for access to important plant genetic resources for food and agriculture. The paper concludes that Australia's best interests are probably in achieving a successful PGRFA Treaty and reconsidering its stance in negotiating the implementation of the PGRFA Treaty to ensure access to key plant genetic resources for food and agriculture essential to Australia's agricultural competitiveness.

\section{2}

\section{INTELLECTUAL PROPERTY RESTRICTIONS UNDER THE PGRFA TREATY}

The PGRFA Treaty establishes a Multilateral System for access to the plant genetic resources for food and agriculture, ${ }^{22}$ subject to benefit sharing arrangements, ${ }^{23}$ and recognising the 'sovereign rights of States over their own plant genetic resources for food and agriculture'. 24 The objective of the PGRFA Treaty is 'the conservation and sustainable use of plant genetic resources for food and agriculture and the fair and equitable sharing of the benefits arising out of their use, in harmony with the CBD, for sustainable agriculture and food security' ${ }^{t 5}$ The term 'plant genetic resources for food and agriculture' is broadly defined, ${ }^{26}$ although in the context of the PGRFA Treaty it is confined to materials included in the Multilateral System that are the list of food crops and forages set out in Annex 1 (see Table 1). ${ }^{27}$ This is further limited as these materials must also be 'under the management and control of the Contracting Parties and in the public domain'.28 The ex situ collections of the Consultative Group on International Agricultural Research ('CGIAR') system of International Agricultural Research Centres $^{29}$ and contributions by other resource holders ${ }^{30}$ also form part of the Multilateral System.

23 Article 10(1).

23 Article 10(2)

Article 10(1).

Article 1(1).

26 Meaning 'any genetic material of plant origin of actual or potential value for food and agriculture' (art 2); the term 'genetic material' is defined to mean 'any material of plant origin, including reproductive and vegetative propagating material, containing functional units of heredity': art 2.

27 Article 11(1).

28 Article 11(2)

29 Article 11(5); according to agreements determined between the Governing Body and International Agricultural Research Centres of CGIAR (art 15(1)): see Commission on 
The materials forming the Multilateral System are accessible to Contracting Parties under standard MTAs between the Governing Body and the accessing party. 31 The PGRFA Treaty imposes a number of mandatory conditions in these MTAs, ${ }^{32}$ including restrictions on claiming intellectual property rights:

Recipients shall not claim any intellectual property or other rights that limit the facilitated access to the plant genetic resources for food and agriculture, or their genetic parts or components, in the form received from the Multilateral System. ${ }^{33}$

However, the meaning of this provision and its effect remain uncertain, particularly the meaning of the terms 'in the form received from the Multilateral System'. This ambiguity was reflected in the draft text, ${ }^{34}$ and remained despite the reservations expressed during negotiations. ${ }^{35}$ Australia's stance during these negotiations is instructive about its likely effect in practice and as an indication of how the Australian government is likely to implement its obligations under the PGRFA Treaty. ${ }^{36}$

During negotiations, Australia commented about the place of intellectual property rights saying:

It will be important also to ensure that an appropriate balance is maintained between guaranteeing continued access to [plant genetic resources for food and agriculture] included in the Multilateral System, and preserving the ability of those carrying out research and development to adequately protect innovations developed using resources that have been accessed under the regime. In this regard, Australia supports the language contained in the second set of square-bracketed text ([in the form receized]) ${ }^{37}$

Australia then expressed some concern about the uncertainty of the language of the proposed intellectual property provision and problems in interpreting the text, and proposed an alternative text qualifying the terms in the form received from the Multilateral System':

Genetic Resources for Food and Agriculture, Renewal of the Agreements Between the International Agricultural Research Centres of the CGLAR and FAO and Draft Reroised Material Transfer Agreement CGRFA-9/02/20 (2002) 1; for a review of the CGIAR centres' structures Ind organisation see Jock Anderson, 'Selected Policy Issues in International Agricultural Research: On Striving for International Public Goods in an Era of Donor Fatigue' (1998) 26 World Deoelopment 1149.

30 Article 11(2); note that Contracting Parties also agreed to 'take appropriate measures to encourage natural and legal persons within their jurisdiction who hold plant genetic resources for food and agriculture listed in Annex $I^{\prime}$ to include such materials in the Multilateral System (art 11(3)), subject to possibly excluding these persons from future access to the Multilateral System (see art 11(4)).

31 Article 12(4).

32 Article 12(4).

33 Article 12(3)(d); the MTA conditions are to apply to subsequent transfers of the Multilateral System's materials: art 12(4).

34 Commission on Genetic Resources for Food and Agriculture, Report of the Commission on Genetic Resources for Food and Agriculture, CGRFA-Ex 6/01/REP (2001) app B(B9).

35 Council of the Food and Agriculture Organization of the United Nations, International Undertaking on Plant Genetic Resources Information Pursuant to Rule XXI.1 of the General Rules

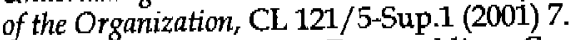

36 Noting that the PGRFA Treaty obliges Contracting Parties to 'ensure the conformity of its laws, regulations and procedures with its obligations as provided in the [PGRFA] Treaty': art 4.

37 CL 121/5-Sup.1, above n 35, 6. 
Table 1 


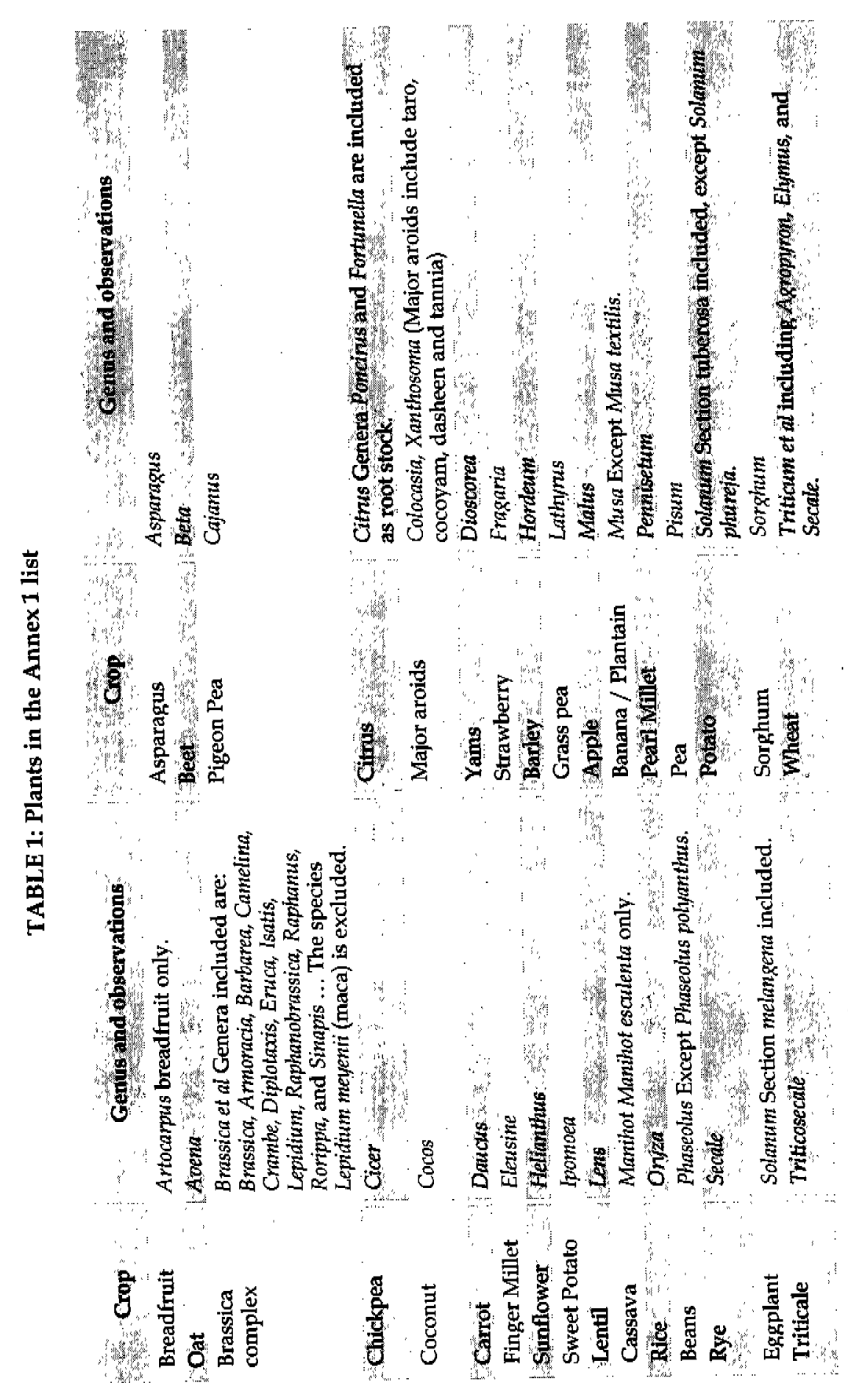


Table 1 cont 


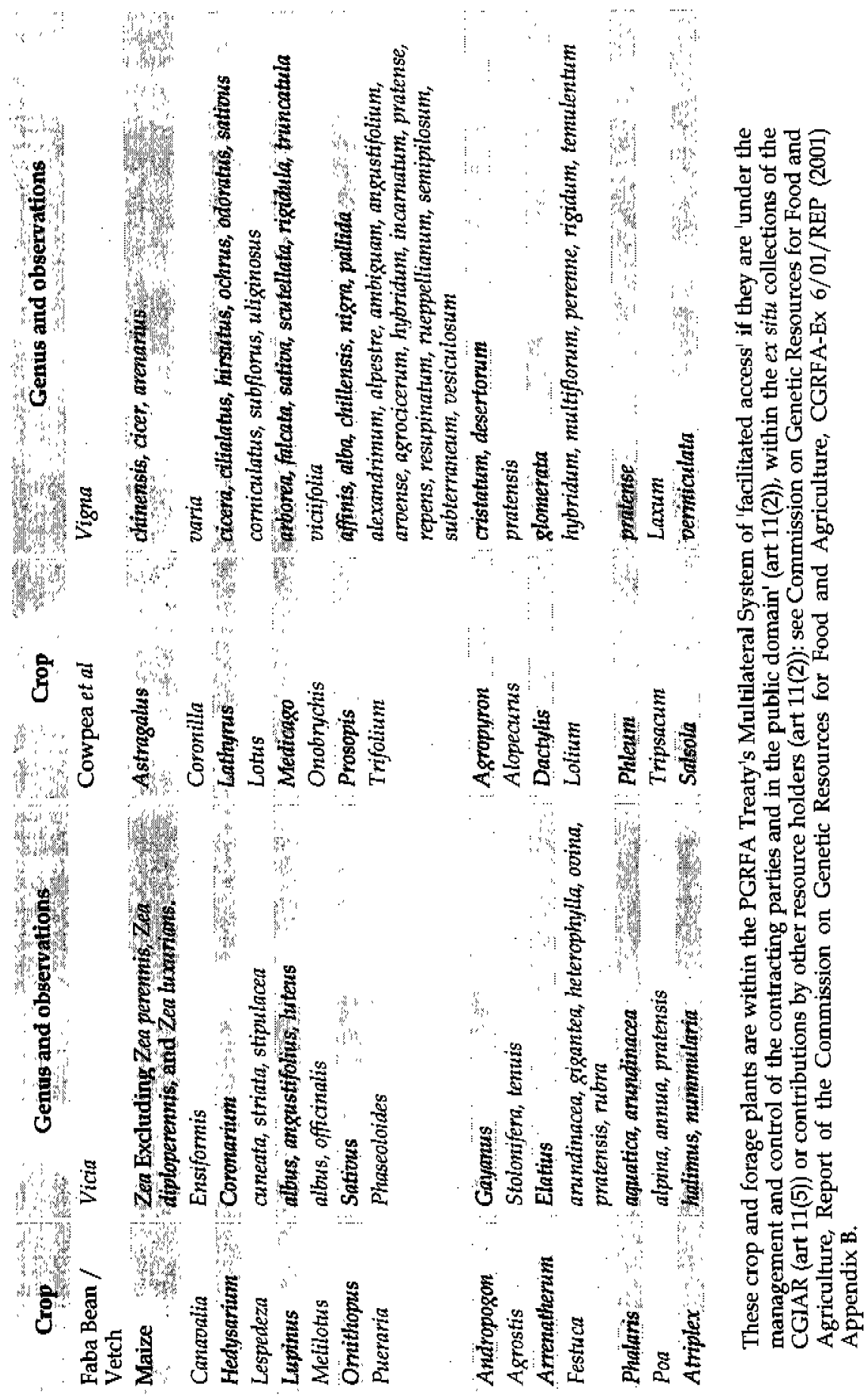


Recipients shall not claim any intellectual property or other rights that limit the facilitated access to the plant genetic resources for food and agriculture, including genetic parts and components, in the form received from the Multilateral System, acknowledging that genetic parts and components that have been modified, for example through isolation and purification, may be patentable provided that the criteria for patentability are met. ${ }^{38}$

The justification for these suggestions was:

Australia's primary concern is to ensure that the final formulation of this provision is clear and enables Australia to continue to exercise its existing rights in accordance with domestic and international law. From an Australian perspective, it is essential that the domestic and international law. From an Australian perspective, it is essential that the final text allows continuation of our domestic policy permitting inds. ${ }^{39}$

rights] protection for genetic material which mion ${ }^{41}$ Japan, $^{42}$ and the United States ${ }^{43}$ expressed similar concerns.

8 Ibid

39 Ibid.

40 Ibid 7-8

$41 \quad$ lbid 14.

42 Ibid 15

43 Ibid 21; as a measure of its reservations the United States had called for a majority vote on entereated 97 votes removing the intellectual property provision entirely, but the concerns the PGRFA Treaty was adopted by 16 ve consis it would consult with its capital on the consistency of States); Japan abstained on the basis it would consult with its capital on the constoristion while the United States abstained on the bases that the intellectual property provision failed to protect intellectual property rights necessary to promote innovation, and its reservations about the ambiguous language of the PGRFA Treaty and a failure to include an essential security clause (for a report on the negotiation and voting see ETC Group, 'The Law of the Seed!' (2001) 3 Translator 1); the proposed United States' essential security provision: '[n]othing in this Undertaking shall be construed to prevent a Contracting Party prom taking any action that it considers necessary for the protection of its essential security interests': CL 121/5-Sup.1, above $n$ 35, 22) the United States later clarified that the absence of an essential security clause 'precluded' it from ever ratifying the PGRFA Treaty (with the effect of excluding the United States from further participation in the PGRFA Treaty's interim committee, although the United States has now signed the PGRFA Treaty (see The United States Mission to the United Nations Agencies in Rome, 'U.S. Signs the International Treaty on Plant Genetic Resources for Food and Agriculture' (Statement, 1 November 2002)) saying:

As a signatory to the Treaty, the United States will actively participate in the development of a standard material transfer agreement under the aegis of the Treaty. The benefit-sharing and intellectual property rights of this material transfer agreement will likely create a de facto global standard for agreements on international exchanges of plant genetic resources. The United States seeks to ensure that this agreement will be simple to administer and that it will promote, not impede, international exchanges of plant genetic resources. The decision to proceed with U.S. ratification, however, will depend on the satisfactory resolution of outstanding issues related to benefit-sharing, intellectual property rights and financial responsibilities.

See also The United States Mission to the European Union, 'U.S. Signs International Plant Genetic Resources Treaty' (Presss Release, 6 November 2002). 
The key intellectual property issue that remains unresolved is to what extent intellectual property rights may be claimed for plant genetic resources that have been originally accessed from the Multilateral System and the quantum of change necessary for materials accessed from the Multilateral System to cease to be 'in the form received from the Multilateral System'. This however, will be influenced by the interaction between the PGRFA Treaty and the CBD, and the likely application to the PGRFA Treaty of minimum standard intellectual property rights required by TRIPS.

The relationship between the PGRFA Treaty and the CBD remains to be determined by the Governing Body 44 and the Conference of the Parties to the CBD. ${ }^{45}$ Presumably the plant genetic resources for food and agriculture accessed from the Multilateral System will substitute, where appropriate, ${ }^{46}$ for the CBD's obligations of prior informed consent, mutually agreed terms, and so on. ${ }^{47}$ This interpretation would be consistent with the PGRFA Treaty's attempt at 'facilitated access' to the Multilateral System's plant genetic resources for food and agriculture. ${ }^{48}$

The Governing Body has not directly addressed the issue of the impact of intellectual property rights on the PGRFA Treaty at this stage, ${ }^{49}$ although this issue goes to the heart of the PGRFA Treaty and is likely to be the determining factor in its entering into force as developed countries seek to privately appropriate the plant genetic resources for food and agriculture through intellectual property rights, and developing and least developed countries and ex situ collection holders (such as the CGIAR centres) seek adequate benefit-sharing and remuneration. 50 While Australia like other developed countries including Japan and the United States) appears to support an interpretation that intellectual property rights may be claimed 'for genetic material which meets relevant standards', 11 other countries favour an interpretation that excludes intellectual property rights over any material obtained under the Multilateral System, even where the relevant standards in national legislation have

44 The Governing Body, composed of all the Contracting Parties, implements the PGRFA The details of its policy, programs and the distribution of the

45 The requirement to co-operate with the Conference of the Parties ('COP') to the CBD is recognised in the PGRFA Treaty: arts 1(1) and 19(3); further the COP to the CBD hision on already decided to establish and maintain cooperation with the FAOs Comitte for the Genetic Resources for Food and Agricalture acting as the Interim Committe fonference of

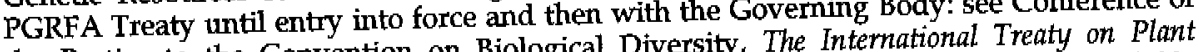
the Parties to the Convention on Biological Diversity, The International Tr/20 (2002) 92. Noting that some of the plant genetione of the CBD, such as the collections of the CGIAR Multilateral System are outside the scope 1993.

47 See art 16

48 Articles 10(2) and 12.

49 Althe Althe PGRFA Treaty provision's words directly into the proposed MTA: see centres that puts the PGRFA Treaty provis

50 Cor a recent analysis of this conflict examining genetic resources under the CBD see Charles For a recent ansan Downing. 'It's Patently Absurd - Benefit-Sharing Genetic Resources Lawson and Susan Downing, 'It's Patenty Absurd - Ben 5 Joumal of Intemational Wildlife from the Selicy 211.

51 See CL 121/5-Sup.1, above n 35, 6. 
been satisfied. 52 However, its seems likely that for Contracting Parties (and the other donors such as the CGIAR centres) contributing materials to the Multilateral System, with the expectation of benefit-sharing in the Multilateral System, they will need to adopt and respect minimum standard intellectual property rights consistent with TRIPS. The PGRFA Treaty itself also appears to support this view.

During negotiation of the PGRFA Treaty text Australia expressed the view that the PGRFA Treaty should '[exist] alongside and [complement] the rights and obligations under existing international instruments ${ }^{\prime 53}$ and that the proposed text did not reflect this and therefore created uncertainty:

Australia considers also that it is necessary and appropriate for the text to be redrafted to reflect the position that the [PGRFA Treaty] would not affect the rights and obligations contained in other existing international instruments. ${ }^{54}$

A suggested text for a separate article making the PGRFA Treaty subservient to all other obligations ${ }^{55}$ was rejected ${ }^{56}$ although its key sentiment was maintained in the PGRFA Treaty's Preamble, which provides:

Affirming that nothing in the [PGRFA] Treaty shall be interpreted as implying in any way a change in the rights and obligations of the Contracting Parties under other international agreements.

That is, the PGRFA Treaty would not change any existing obligations under the That, most importantly TRIPS, as both the CBD and TRIPS have entered into force and bind Australia. The effect of this requirement is to impose the minimum patenting tandards required by TRIPS. From Australia's perspective this presumably means that change from 'in the form received from the Multilateral System' that satisfies the any change from 'in the form rect or PBR under the Plant Breeder's

threshold criteria for patenting under the Patents Act or PBR und would be sufficient to satisfy both the PGRFA Treaty and TRIPS obligations.

In practice, the thresholds for patenting under the Patents Act or PBRs under the Plant Breeder's Rights Act are easily satisfied for biological materials so that statutory rights may be claimed over these plant genetic resources for food and agriculture, and their parts and components, with very, very little change (whether innovials that breeding). ${ }^{57}$ This is significant as patent claims and/or PBRs ${ }^{58}$ over mater
cease to be 'in the form received from the Multilateral System' may in effect:

52 For example, Norway considers that '[g]iven the fact that the backbone of the multilateral system now is material in the public domain, it is even more important to avoid any possibilities of "leakage" of material (or options for use) from the system': ibid 17.

53 Ibid 7.

54 Ibid.

55 See CGRFA-Ex 6/01/REP, above n 34, app B(B5)

56 See ETC Group, above n 43,3 .

57 See various reports about patenting biological materials: Charles Lawson, 'Patenting Genes and Gene Sequences and Competition: Patenting at the Cxpense of Competition' (2002) 30 Federal Law Review 97; Charles Lawson and Catherine Pickering, 'Patenting Genetic Materials - Failing to Reflect the Value of Variation in DNA Pickering 'Panino Acids' (2000) 11 Australian Intellectual Property loumal 69; Charles Lawson, RNA and Amino Acids' (2000) 11 Australian Intellectual Property Joumal 69, Charles Lawson Patenting Genetic Materials - Old Rules May Be Restricting the Exploitation of a New Technology' (1999) 6 Journal of Law and Medicine 373; Dianne Nicol, 'Should Human Genes be Patentable Inventions under Australian Law?' (1996) 3 Journal of Law and Medicine 231. 
(a) Remove the patented or PBRed materials from the public domain or the management and control of the Contracting Party and so outside the PGRFA Treaty's Multilateral System. These materials will then no longer be subject to the PGRFA Treaty's 'facilitated access' scheme;

(b) Extend to the materials accessed from the Multilateral System, ${ }^{59}$ as well as other materials within the Multilateral System, including materials that may only be vaguely related to the accessed materials, ${ }^{60}$ where the patent broadly claims related materials; and

(c) Remove subsequent improvements to the materials that cease to be a part of the Multilateral System unless the patent or PBR holder (or their successors) again contributes the materials to the Multilateral System.

The consequences of these arrangements for Australia's agricultural policy settings are considered further in Part 4. However, until the PGRFA Treaty enters into force, the CBD access scheme that deals with all genetic resources (except the ex situ collections before 29 December 1993) is the binding arrangement on Australia. Further, even after the PGRFA Treaty enters into force the CBD's scheme will apply to important crop and forage plants that do not form part of the PGRFA Treaty's Multilateral System. Table 2 sets out examples of plant genetic resources for food and agriculture that were expressly excluded from the Multilateral System during negotiation of the final PGRFA Treaty text. The effects of intellectual property rights under the $\mathrm{CBD}$ are therefore significant and an integral part of considering Australia's agricultural policy settings.

The CBD has the objective of conserving biological diversity (which includes genetic diversity), its sustainable use and the

fair and equitable sharing of the benefits arising out of the utilization of genetic resources including by appropriate access to genetic resources and by appropriate transfer of relevant technologies, taking into account all rights over those resources and to technologies, and by appropriate funding. ${ }^{61}$

58 The Patents Act 1990 (Cth) and Plant Breeder's Rights Act 1994 (Cth) co-exist leaving the inventor or breeder to determine the best scheme to approach for their innovation; see $\mathrm{IP}$ Australia, Australian Patents for Plants (2002) 1.

59 Such as a claim to a process for using parental strains to make the invention that is the F1 progeny: see, eg, DNA Plant Technology Corporation, New Pepper Variety, Australian Standard Patent Application 200143267 (2001).

60 See for examples of broad claims to genetic materials Lawson, 'Patenting Genetic Materials', above n 57, 381-4.

61 Article 1. 
Table 2 


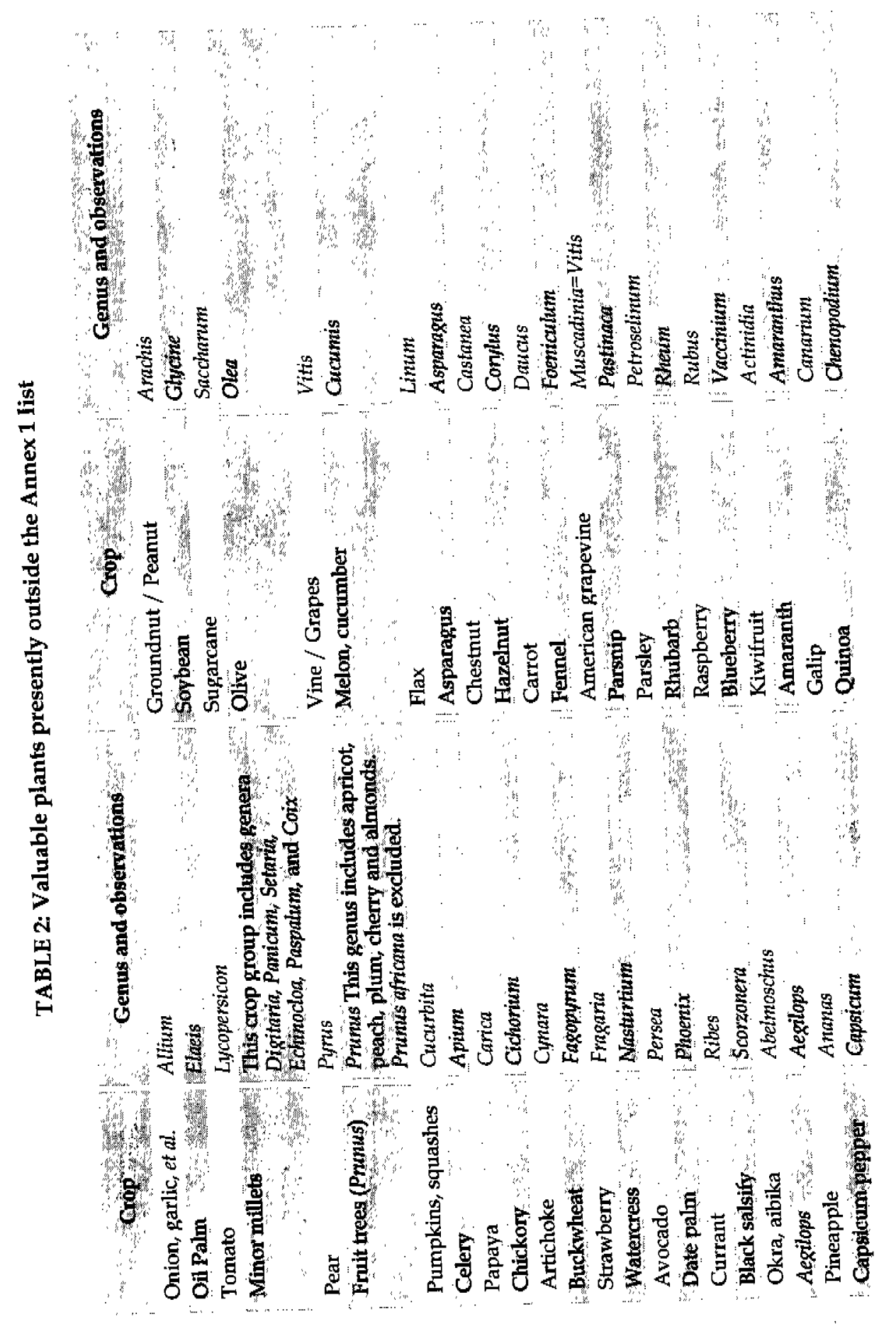


Table 2 cont 


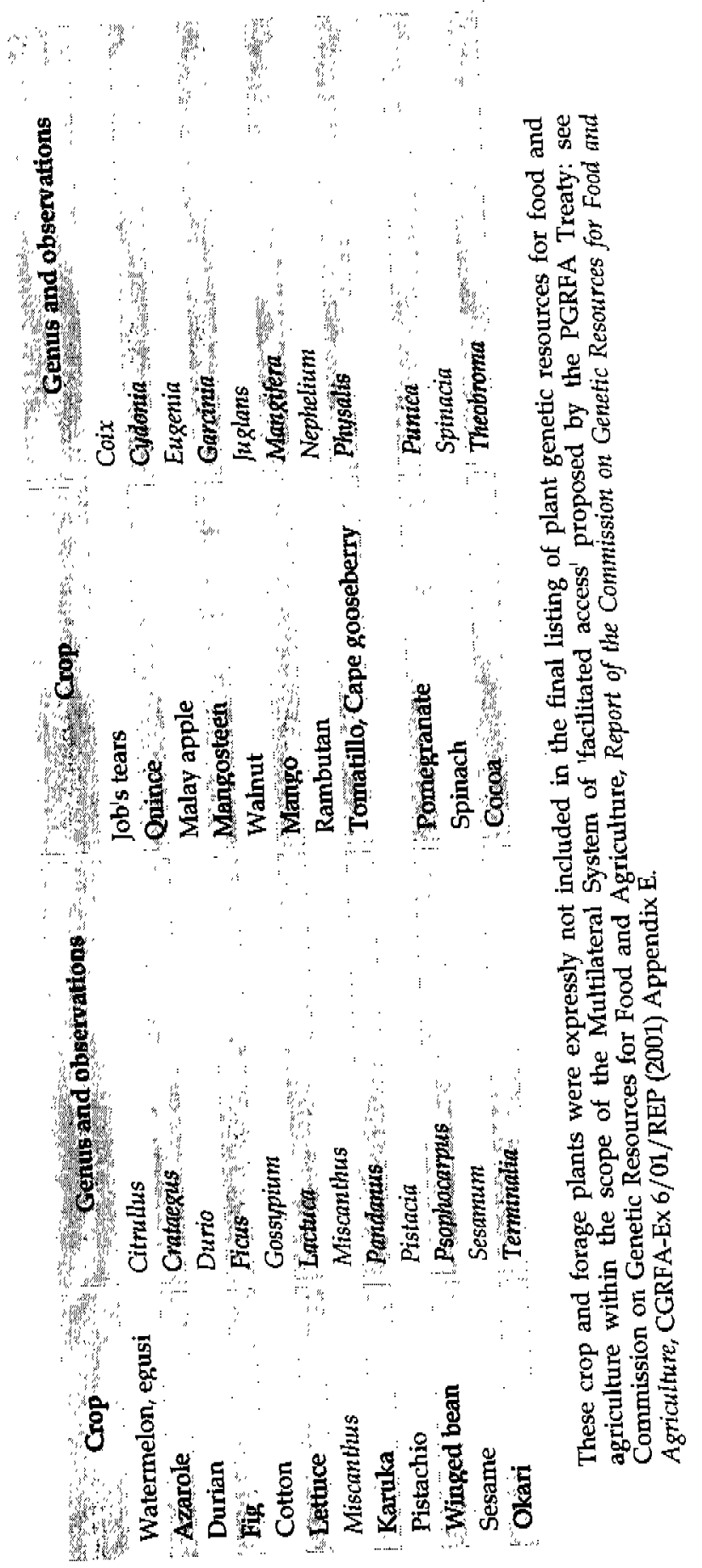


The term 'genetic resources' is broadly defined to mean 'genetic material of actual or 'genetic material' means 'any material of plant, animal, microbial or other origin containing functional units of heredity'. ${ }^{62}$ Access to genetic resources is according to the authority of countries ${ }^{63}$ with an obligation to facilitate access for 'environmentally sound uses' without imposing restrictions counter to the CBD's objectives. ${ }^{64}$ Further, access must be from countries of origin or countries that have acquired the genetic resources according to the $\mathrm{CBD}^{65}$ on

with prior informed consent, ${ }^{67}$ and most importandy, taking legislative, administrative or policy measures, as appropriate, and in accordnology and Articles 16 [access to and transfer of technology] and through the financial mechanism distribution of its benefits] and where necessar 21 [financial mechanism] with the aim established by Articles 20 [financial resources] and 21 [financh and development and the of sharing in a fair and equitable way the results of research and genetic resources with the benefits arising from the commercial and other

In dealing with the access to and transfer of technology, the CBD provides:

Contracting Party, recognising that technology includes biotechnology, and that both for the elements for the attainment of the objectives of this Contate access for and transfer to other provisions of this Article [16] to provide and/or facilitate access forvation and sustainable Contracting Parties of technologies that are relevant to the conservation and sustaigiant use of biological diversity or mak damage to the environment.
Where access to and transfer of technology are made to developing countries, ${ }^{70}$ and
(uscess the technology is 'subject to patents and other intellectual pro are consistent with the and transfer shall be provided on terms which recognze and are $^{71}$ For other countries adequate and effective protection of intellectual property rights technology 'protected (presumably developed countries), the access to and' in exchange for access to genetic by patents and other intellectual propertional law ${ }^{172}$ In each instance however:

resources must be in accordance with international law' The Contracting Parties, recognizing that patents and other intellectual prepe in this regard
may have an influence on the implementation of this [CBD], shall cooperate in

Article 15(1).

Article 15(2)

Article 15(3)

Article 15(4)

Article 15(5).

Article 15(7).

Article 16(1).

It 'shall be provided and/or facilitated under fair and most favourable terms, including on concessional and preferential terms where mutually agreed, and where necessary in ith the financial mechanism established by Articles 20 and 21': art 16(2); accordance with the financial mechanism estabing and least developed countries as presumably this also includes

71 Article 16(2)

72 Article 16(3) 
subject to national legislation and international law in order to ensure that such rights are

supportive of and do not run counter to its objectives. ${ }^{73}$ intellectual property rights on

The CBD Secretariat's early review of the impact of intellectual property rights are a favoured the CBD's objectives reinforced the view that intable sharing of the benefits of genetic mechanism for achieving access and the various CBD and WTO/TRIPS resources. ${ }^{74}$ However, subsequent analysis by view about the interaction of emanations has been unable to articulate a coherent intellectual property rights and the $\mathrm{CBD}^{75}$ and the analysious member countries ${ }^{77}$ probably reflects the negotiating positions of the hindered technology transfer and developing countries argued that strong pats and therefore these countries generally disregarded the contributions of family farmers and theres argued that strong patents favoured restricting patents, ${ }^{7}$ whlle deversity by encouraging technology transfer, created incentives to conserve biodively outcome is that countries providing access investment and development. to their genetic resources according to developed countries) will need to adopt and of technology (from predominantly devely rights. ${ }^{80}$ For Australia these standards and PBRs under the Plant Breeder's are articulated as patents under the Patents Act and PBRs unded by TRIPS.

Rights Act that are consistent with the minimum stand CBD are The internationally contested inherent conflicts between IRIPS and the prenis plant
that TRIPS requires genetic materials be protected by patents or sui generis

73 Article 16(5)

74 Conference of Parties to the Convention on Biological Diversity, The Impact of Intellectual Property Rights Systems on the Conservation and Sustainable Use of Biologis (1996) 4.

Property Rights Systems on the Conserits Use, UNEP/CBD/COP/3/22 (1996) 4 .
the Equitable Sharing of Benefits from its of the Ad
75 See, eg, Conference of Parties to the Convention on Biological Diversity, Report of 6 (2001); Hoc Open-Ended Working Group on Access and Benefi-Shar Diversity, Access and Benefit-Sharing Conference of Parties to the Convention on B/OS/ $/ 6 / 19$ (2002); Ad Hoc Open Ended as Related to Genetic Resources, UNEP/CBD/COP/6/19ting on the Role of Intellectual Property Working Group on Access and Benefit-Shang Rharing Arrangements, UNEP/CBD/WGRights in the Implementation of Access and Beneft-Shancil for Trade-Related Aspects of ABS/1/4 (2001); World Trade Organization Cowneen the TRIPS Agreement and the Intellectual Property Rights, The Relationship Bes Raised and Points Made, $\mathrm{IP} / \mathrm{C} / \mathrm{W} / 368$ Convention on Biological Diversity -

(2002) (and the references $/ \mathrm{COP} / 6 / 19$, above $n$ 75.

77 See generally UNEP/CBD/COP $/ 3 / 22$, above $n 74$.

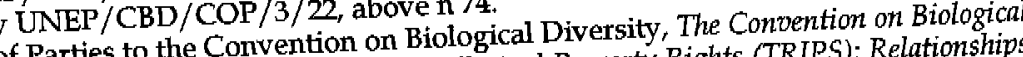
Dioersity and the Agreement on Trade-Related Intellectual Property Rights (TRIPS): Relationships and Symergies, UNEP/CBD/COP/3/23 (1996) 4; eg, Malaysia declared: My delegation wishes to state that the terms of transfer of technology referred to in Artice 16 (2) dratd be fully reflect the position of my country which requires that such tranization Committee specifically on concessional and preferential terms . WT/CTE/W/8 (1995) Annex 5.

the United States declared: '[i]t is deeply

$\mathrm{UNEP} / \mathrm{CBD} / \mathrm{COP} / 3 / 23$, above $n$ 7, 4 , regrettable to us that ... a number of issues of this negotiation. As a result, in our view, the been adequately addressed in the course of this negotiation. As a result, in our above $n 78$,
test is seriously flawed in a number of important respects': WT/CTE/W/8, above

Annex 5.

For a further analysis of this claim see Lawson and Downing, above $\mathrm{n} 50,224$. 
variety rights and that this privately appropriates genetic resources over which a

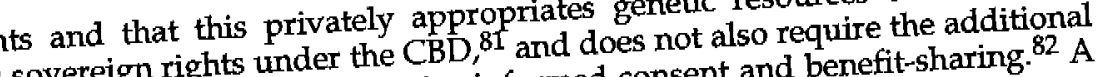
country has sover in the $\mathrm{CBD}$, such as prior informed consent and benefit-sharing. measures set out in that patents over genetic materials and their apped by the appropriate genetic resources independently of the access scheme propoptured by $\mathrm{CBD}$ and that the benefits of

non-resident rights holders. ${ }^{83}$ of the Parties to the CBD ('COP') continues to develop

However, the Conference of the Parties to thess and benefit-sharing despite the and investigate practical measures to address access and bened ${ }^{84}$ For example, the interaction between the CBD and TRIPS remaining Genetic Resources and Fair and COP has adopted the Bonn Guidelines on Access to Genetic Resources addelines') ${ }^{85}$ as Equitable Sharing of the Benefits Arising out of their Utilizations about access and benefitvoluntary guidelines to implementing the CBD provisions about access and by the sharing. These guidelines are intended to apply to all genetic res that is 'coherent and CBD (except human genetic resources), apply in international agreements and mutually supportive of the work of relevant PGRFA Treaty. 88 The guidelines institutions ${ }^{187}$ and be 'without prejudice' to the propose the establishment of a competent the origin of genetic resources and the responsibilities of Contracting Parties that are the origines also set out the steps in the implementation of mutually agreed terms. The guidelines do not appear to favour a implementation of muturing process.91 While these guidelines do not appear the
specific approach to intellectual property rights, they are consistent with the COP's

Group, see World Trade Organization Council for Trade-

81 Kenya, on behalf of the African Group, see Work Triew of the Provisions of Article 27.3(b) Related Aspects of Intellectual Property Rights, Reotew of the IP/C/W/163 (1999); see also Communication from Kenya

Council for Trade-Related Aspects of Intellectual Property World Trade Organization Council for Tration Rappard on 21 and 22 September 2000 Rights, Minutes of Meeting Held in the Centre William Rapp 2.

IP/C/M/28 (2000) 43; see also IP/C/W/368, aboric 'Controlling Access to Genetic Resources

Charles Lawson and Catherine Pickering, 'Controling Access 1999 (Cth) Requires an See Charles Lawson and Catherine Protection and Biodiversity Conservation Act 1999 (Cth) Requires an
under the Environment Proter (Cth)' (2002) 13 Australian Intellectual
Assessment of the Effects of the Patents Act 1990 ( 50 ; Charles Lawson and Catherine Property Journal 109; Lawson and Downing above $n$, Cher the Conoention on Biological Pickering, 'The Conflict for Patented Genetic Mater of Intellectual Property Rights' (2001) 12 Diversity and the Agreement on Trade Related

Trade Organization to acknowledge

84 For example, the COP resolved to invite the Worthe relevant provisions of the [CBD] and to take into account the fact the this interrelationship': [TRIPS] and the [CBD] are interrelated and to fur Diversity, Access to Genetic Resources, Conference of Parties to the Convention on Biological

200. Diversity, Access and Benefit-Sharing

85 Conference of Parties to the Convention on Biological Diversity, A/6/20 (2002) 262

as Related to Genetic Resources, Decision VI/24A,

86 Article 9.

87 Article 10.

88 Article 10

89 Article 14.

90 Article 16

91 Articles 22-50. 
view (together with the World Intellectual Property Organization, ${ }^{92}$ the TRIPS Counci ${ }^{93}$ and the Australian government ${ }^{94}$ among others) that contracts addressing intellectual property rights and other matters between the resource holder and the exploiter dealing with the access and benefit-sharing arrangements are preferable.95 Despite these developments, significant concerns from the developing countries about the effect of intellectual property rights and equitably sharing the benefits remain unresolved. ${ }^{96}$

Further, there are some significant limitations to the CBD's access scheme as it does not apply to ex situ collections before 29 December 1993 when the CBD entered into force $^{97}$ and it does not bind all countries (most notably the United States). ${ }^{98}$ Thus access to these resources will require separate access negotiation with no agreed frameworks under the CBD.

The likely consequences for accessing materials under the CBD's scheme will be negotiating an access agreement with the resource holder in the country of origin according to the CBD and voluntary guidelines, an access agreement with the acquirer ces where access was in accordance with the CBD, or a separate access Desource is outside the scope of the agreement with the resource holder where the resource is out the use of subsequent CBD. In each instance, the use of the accessed materials access agreement. As these improvements will be according to the terms of the access agreed countries with agreements can be expected to be predominantly between develty rights are likely to technology that can use the genetic resources, indards required by TRIPS and favoured be consistent with, at least, the minimum standard these arrangements for Australia's

by the developed countries. The consequences of these arrat
agricultural policy settings are considered further in Part 4.

92 See, eg, Intergovernmental Committee on Intellectual Property and Genetic Resources, Krowledge and Folklore of the World Intellectual Property Organization, Operational Principles for Intellectual Property Clauses of Contractual Agreements Concerning Ppention to Getic Resources and Benefit-Sharing, WTPO/GRTKF/IC/2/3 (2001)

$93 \mathrm{See}$, eg, IP/C/W/368, above n 75.

(to Biological Resources in Conmonurealth Areas (2000); regulations have been proposed to put the outcome of contracting into effect.

95 See UNEP/CBD/COP/6/6, above $n 75$. like-minded mega-diversity countries seeking to

96 See, eg, the recent Cancun Declaration by like-minded mega-diversity the Convention on protect their particular interests as a block: Conference of Parties to the Convention Biological Diversity, Cancun De

UNEP/CBD/COP/6/INF/33 (2002).

97 See Conference of Parties to the Convention on Biological Diversity, Access to Gomation, Resources and Benefit-Sharing.

98 UNEP/CBD/COP/2/13 (1995) 17 . Cambodia, Equatorial Guinea, Eritrea, Georgia, Holy See, Iraq, Kiribati. Kyrgyzstan, Lao People's Democratic Republic, Niue, Palau, Saint Lucia Saint Vincent and the Grenadines, Saudi Arabia, Sierra Leone, Somalia, Tajikistan, Thailand, The Former Yugoslav Republic of Macedonia, Tonga, Turkmenistan and Uzbekistan. 


\section{CONCLUSIONS}

Patents and PBRs are a blunt economic tool to promote investment in useful innovations and address innovation market failure. Their suitability to second-order developed economies, like Australia, is still open to speculation with consequences for the policy settings that might be adopted in imp:

requirements of the PGRFA Treaty and CBD. Thus the highly protective [patenting]

There are legitimate reasons to be concemed about the highly prote European Union.

standards that have emerged recently in the United broad patent protection for ...

These laws and judicial interpretations pro seen whether such standards tilt the

biotechnological inventions .... It remains to be seen whis of inventors and away from

balance within those jurisdictions toward the private rights of invento are inappropriate the needs of competitors and users. It is not too early to 99

for developing economies and net technology importers.
Significantly, Australia is a net technology importer, 100 and whilst its status as a
ind developed country is certain, its economy is of a very irst-order developed nations. 101 States, Japan and the United Kingdom, which ather developed countries (such as the Further, analyses of patent grants betw for Economic Co-operation and Development member countries of the Organisation for Economior agricultural export destinations ('OECD'); see Table 3) and among Australia's Japan patent considerably more than (see Table 4) shows that the United Statia's major agricultural export destinations, the other countries. Significantly, of Australia's major agent grants (approximately 64 per United States holds the majority of non-resident patent ger 51 per cent; see Table 5). cent) and non-resident PBR registration (approximation of Australia's total patent Further, the United States holds a significant proports and 49 per cent of non-resident grants (approximately 44 per cent of total pat

99 Keith Maskus, Intellectual Property Rights in the Global Economy (2000) 237-8. 100 See, eg, the compiled data of trade in patent-dependant (Staff Research Paper, Productivity 'Trade-Related Aspects of

Commission, 1999) 61:

comparing the Australian data with the overseas data from 1989 reveals that in recent years, Australia has a greater proportion of imports which atent-related related than any of the other cotuntries examined. Oustrialised countries, and goods in exports is lower than in most indry like Portugal. The reason comparable to that of a semi-industrialised counce on the exports of primary for this is Australia's traditional reliance on thermed manufactures. The commodities and the imports of elaborately timports has in fact narrowed in difference between patent-related exports and imports has in fact narroweled recent years. It is worth noting from the figures that the shachology exporting recent yearts in trade is particularly high in the leading technology expory (at
countries such as the United States, Japan, United Kingdom and Germany 62).

101 For example, Gross Domestic Product ('GDP') at 1995 prices and 1995 exchange rates for 2002 in billions of United States dollars: Australia - 484.6, United States - 9conomic Co- 5606.5, Canada - 741.4 and United Kingdom -- 1354.9: Organisaton 247; while the value operation and Development, Main Economic Indicators (March forestry and fishing) for a added in agriculture as a per cent of GDP (including han - 13, Canada -2.6 and United similar period: Australia - 3.5, United States - 1.6, Japan - 1.3, Cand Development, Main Kingdom - 0.9: Organisation for Econ

Economic Indicators (December 2002) 272-5. 
Table 3 


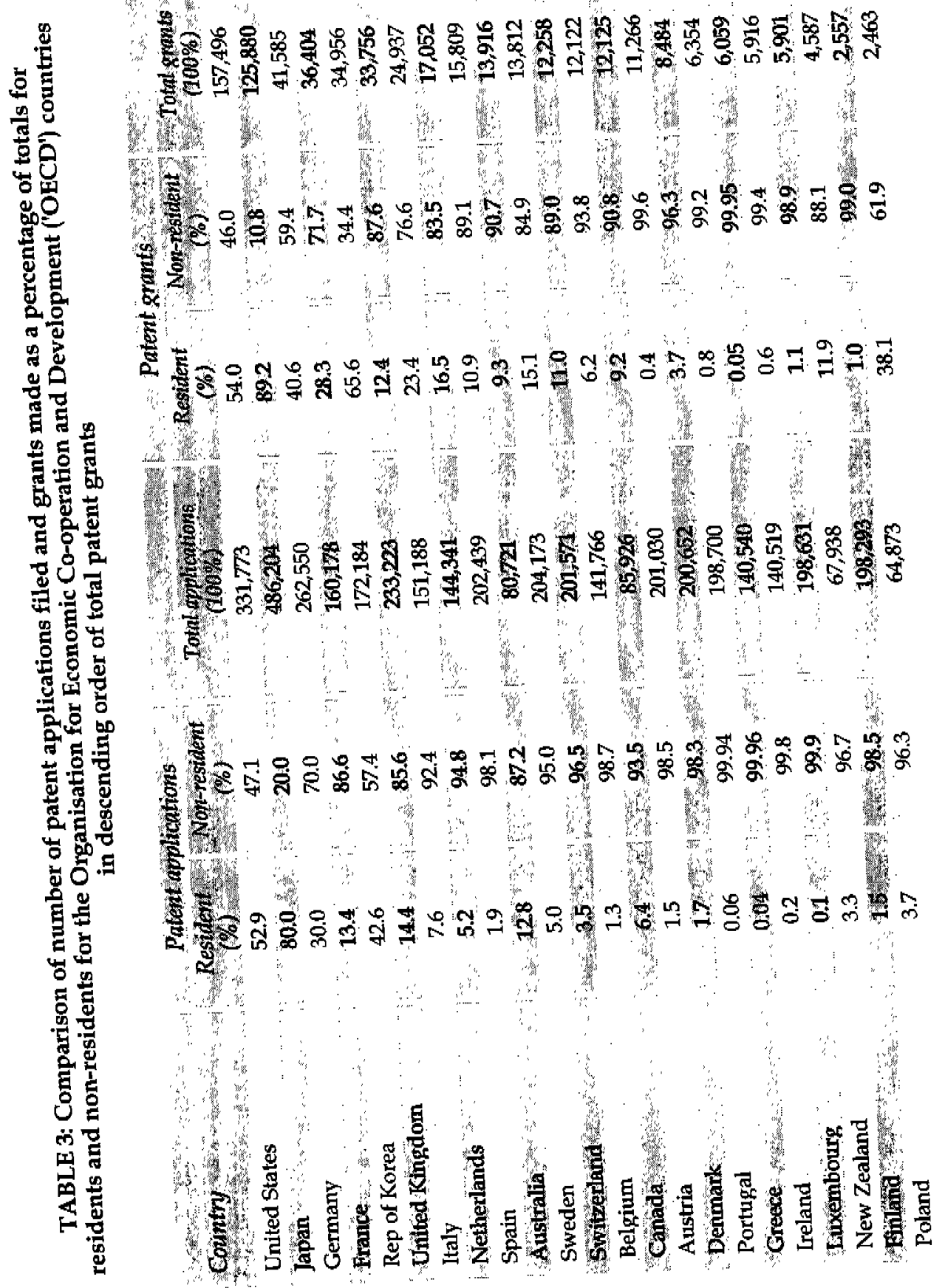


Table 3 cont 


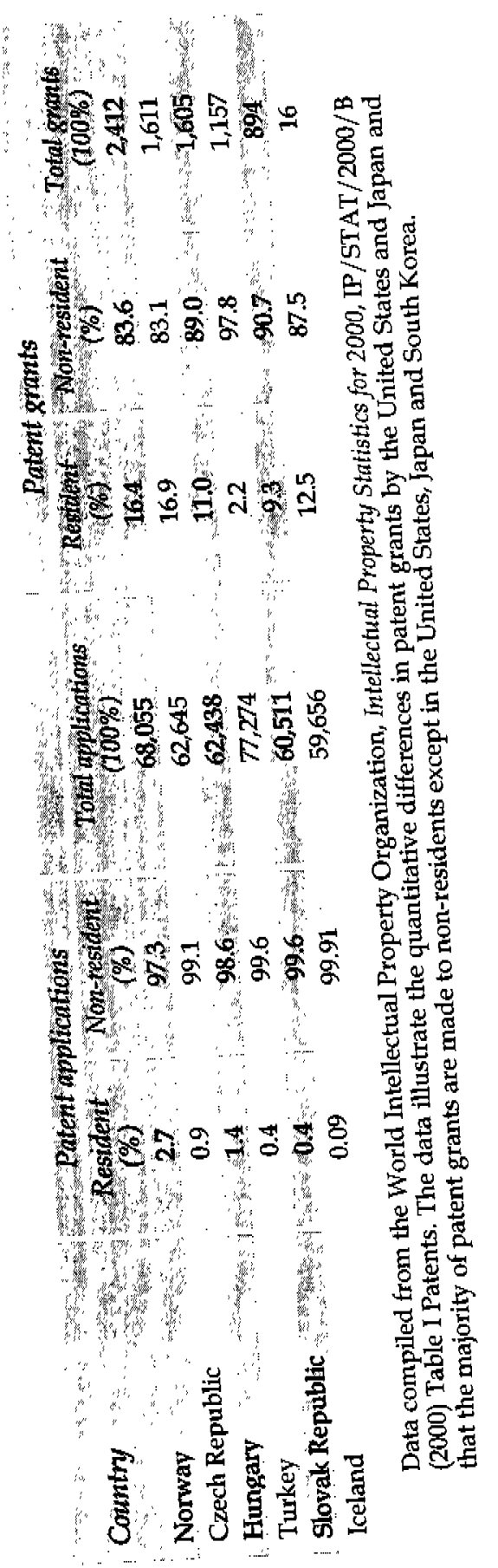


TABLE 4: Australia's major exports of agriculture (excluding fisheries, forestry and rubber) in 2002

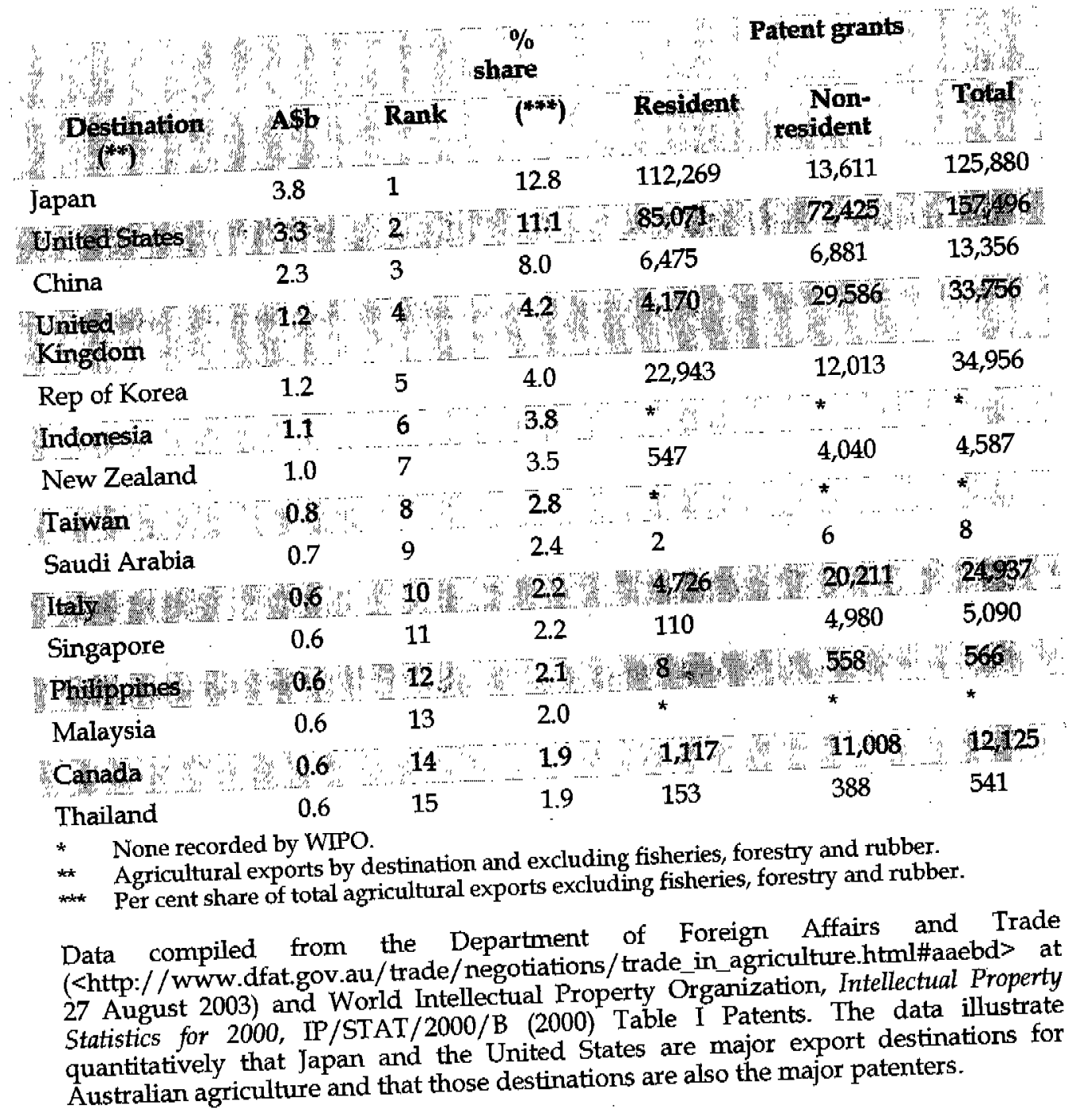


patent grants in Australia in 2000; Tables 3 and 5) and PBR registrations (approximately 16 per cent in 2000; Tables 5 and 6) compared to other countries. In contrast, Japan is marked by a majority of resident patent grants (approximately 89 per cent; Table 3) and limited non-resident patenting (approximately 13 per cent of nonresident patent grants in Australia; Table 5). The United Kingdom and other OECD countries (see Tables 3 and 5) are in a similar position to Australia with the majority of patent grants to non-residents (between approximately 60 and 99 per cent; Table 3) and United States residents holding the majority of these non-resident grants. ${ }^{102}$ In these circumstances the policy considerations about the place of intellectual property rights in Australian agriculture are different to those of the first-order developed countries (such as the United States and Japan). They are also different to those of developing and least developed countries. ${ }^{103}$ Thus, the benefits and costs to Australia in implementing the PGRFA Treaty and the access and benefit-sharing scheme in the CBD are unlikely to be those of the first-order developed countries or the developing (or least developed) countries, but rather a compromise that reflects Australia's particular commercial and environmental interests. The particular interrelated issues that Australia faces are:

(a) Non-residents holding the majority of patents (see Table 3) and PBRs (see Table 6) in Australia, so residents can increasingly be expected to have to negotiate with non-resident rights holders (and most probably United States residents; see Tables 3 and 5) to access and use their protected useful plant genetic resources for food and agriculture, and most importantly, the know-how and other technology to make and then use those protected genetic resources. These nonresident intellectual property rights reduce the likely economic benefit to Australia from agricultural exports as there will be further economic rents from patents and PBR royalties over accessed and used plant genetic resources for food and agriculture;

(b) The evolving market structures for global agriculture show a consolidation of corporations, 104 in particular the seed market, with real increases in seed prices in recent decades compared to yields. ${ }^{105}$ Further, multi-national seed corporations relying on economies of scale are likely to undertake their variety development and seed production activities in a limited number of locations. 106 The effect of this market concentration is likely to be higher priced seeds and germplasm and directed to a limited number of crop and forage plants suited to environments of the major high value markets in North America and Europe;

$\overline{102}$ See World Intellectual Property Organization, Intellectual Property Statistics for 2000, IP/STAT / 2000/B (2000) Table I Patents.

103 For an altemative analysis of patent applications and grants among the developing and least developed countries that hold most of the world's genetic diversity see Lawson and Downing, above $n 50$.

104 There is a considerable literature on this matter: see, eg, Richard Hindmarsh, 'Consolidating Control: Plant Variety Rights, Genes and Seeds' (1999) 44 Journal of Australian Political Economy 58; William Lesser, 'Intellectual Property Rights and Concentration in Agricultural Biotechnology' (1998) 1 AgBio Forum 56.

105 See review in Rangnekar, above n 6, 13-14 (and the references therein). 
(c) As a consequence of market concentration, increasing patent holdings over plant genetic resources for food and agriculture in the earliest stages of crop and forage plant development have the potential to control the subsequent steps in the commercial exploitation of the new variety through vertical integration and restrictive contractual access practices. ${ }^{107}$ Pro-competion and restrictive practices limit the anti-competitive effects of vertical the 'purpose and scope' of the patent are also unlikely to limit activities withection of effective pro-competition laws or PBR in Australia. ${ }^{108}$ Without the protection of efices and enjoy limited access, Australian agriculture can expect to pay high products might be competing against especially where Australian agricultural products might bectual property rights other mark

(d) As a further consequence of market concentration and the increased focus of those corporations on crops amenable to appropriation and developed for exclusive agro-ecological zones, the role of research in Australia to develop plant varieties suited to Australia's environment will be vital. It is uncertain that sertor research on will develop varieties suitable to Australia's environment and its interests. Thus, public sector research is likely to be vital to plant varieties from elite germplasm and these will incur additional expense and restrictions if the plant genetic resources for food and agriculture are not freely available; and

(e) The relatively few crop and forage plants with a high commercial value are likely to attract the major attention of those seeking to commercialise and dominate the particular commodity or niche markets of developed countries. The breeding effort undertaken by the increasingly consolidated agricultural corporations tends to be on a few high value crops amenable to appropriation and developed for exclusive agro-ecological zones. 109 With many and diffuse patents and PBRs over plants and plant varieties (including patent 'clustering' and 'bracketing'), 110 potential users will be required to determine the scope of uncertain rights and then negotiate successfully with all the relevant parties for products and processes that may not be best suited to Australia. This poses ing for Australian breeders and exporters as they will be negotiate access to develop new varieties whose products are likely to compete against the original rights holders in their domestic and foreign it is not certain that Australia's competition laws are adequate to markets. Again, it is not certain that Ace of non-resident patented and PBRed plant ensure reasonable access and materials for food and agriculture.

106 See Frederic Scherer and David Ross, Industrial Market Structure and Economic Performance (3rd ed, 1990) 625-6.

107 For a detailed analysis of the value chain and the role of patents see Kesan, above $n$ 13, 46676.

analysis of the limitations of the Trade Practices Act 1974 (Cth) applying to patented genes and gene sequences: Lawson, Patenting Genes and Gene Sequences and Competition', above $n$ 57, 115-28.

109 See Rangnekar, above $n 6,15$.

ally Ove Granstrand, The Economics and Managentent of Intellectual Property: Towoards Intellectual Capitalism (1999). 
Table 5 


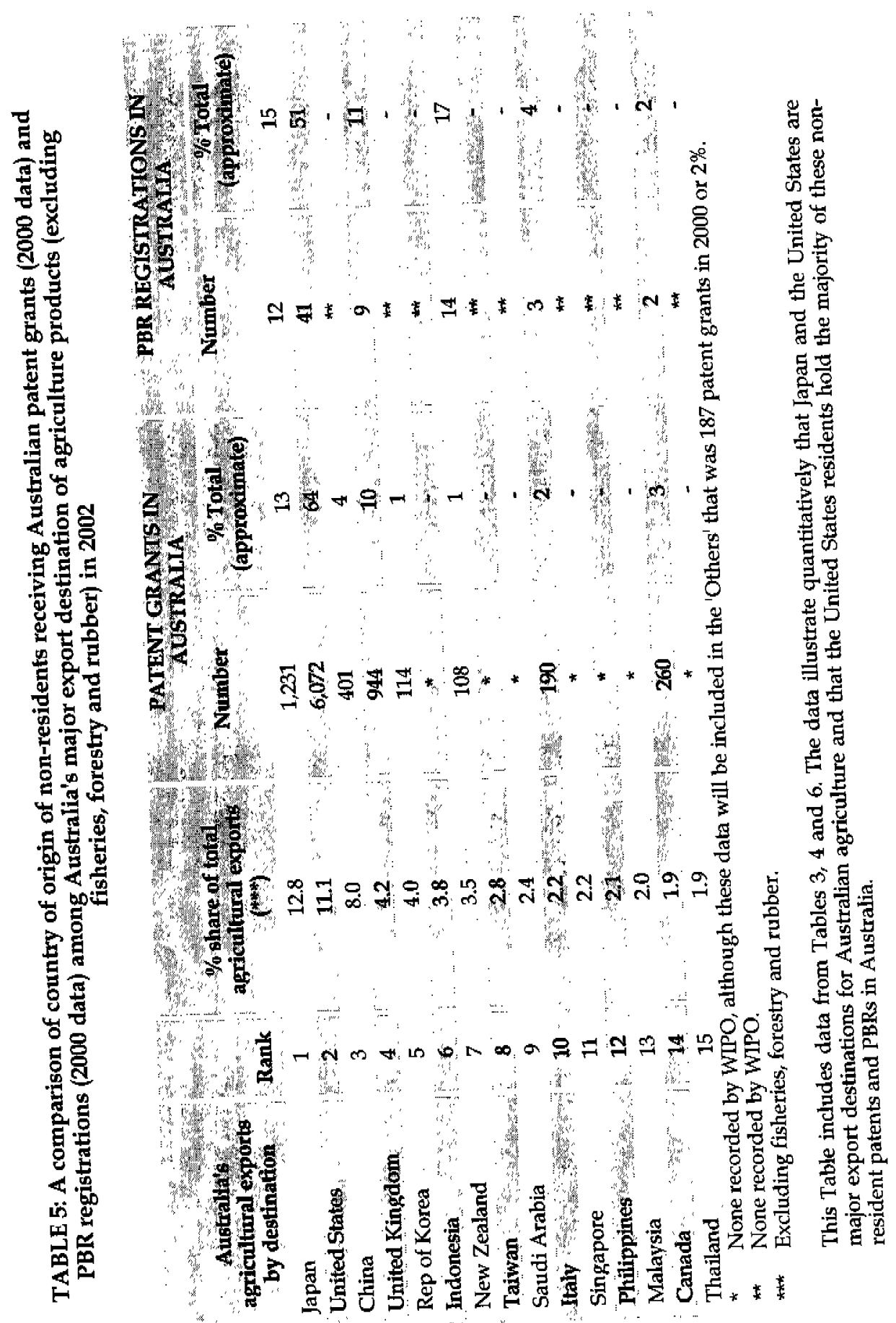


Table 6 


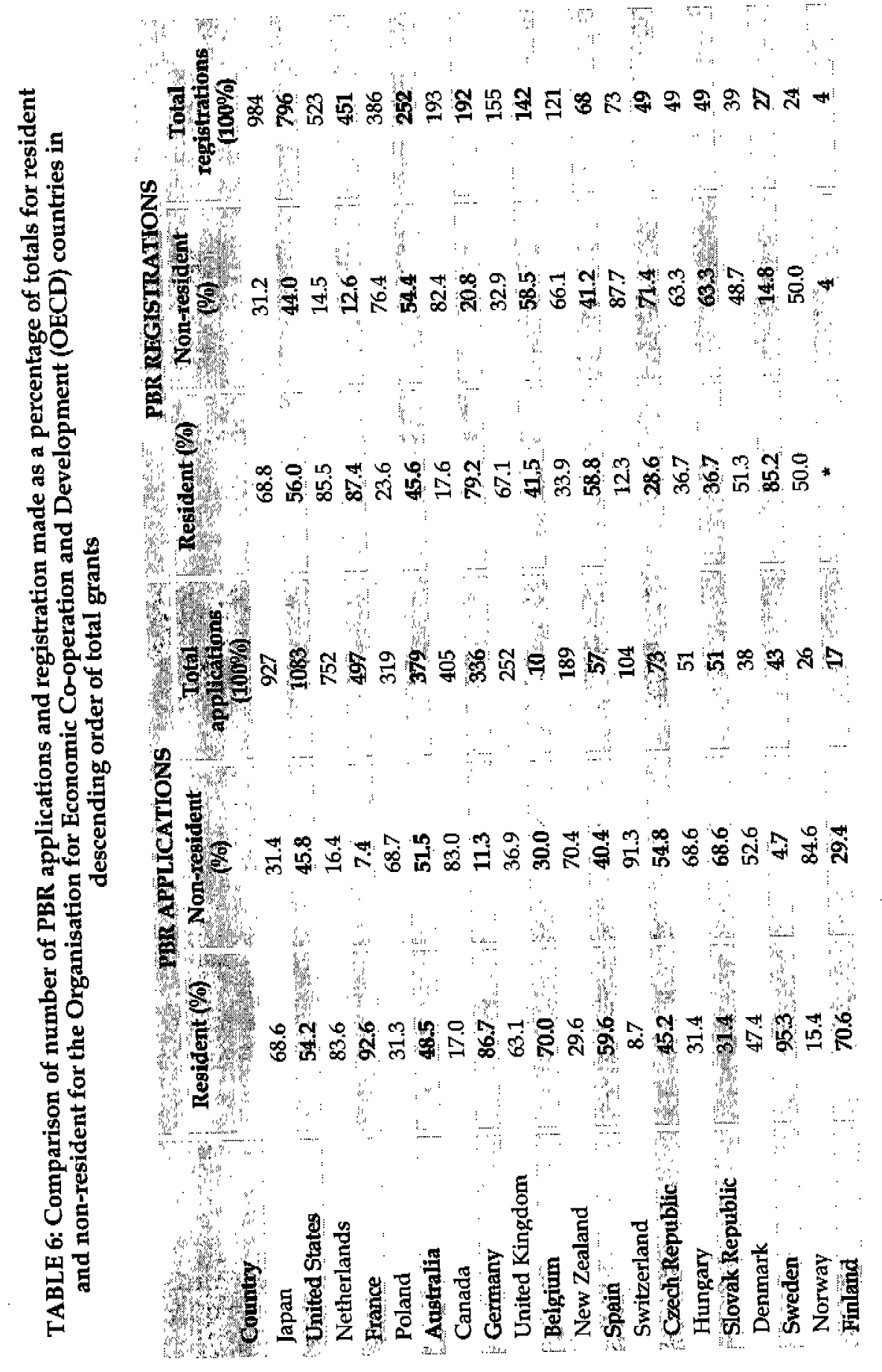


Table 6 cont 


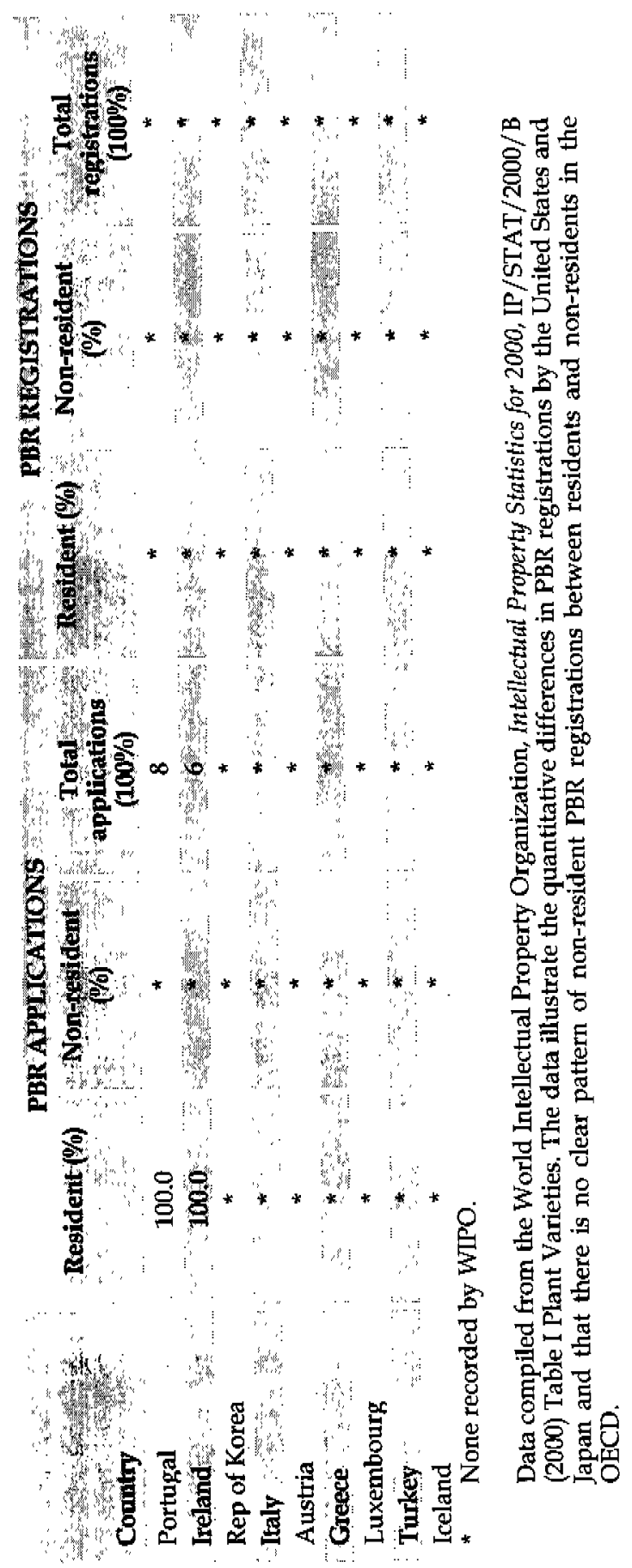


Thus, the significant issue for developing new plant varieties for Australia's agricultural and environmental landscape is whether patent holders of plant varieties do in fact limit breeding, either expressly by refusing access to their invention, or in effect by breeders giving up or failing to commence new development where the plant genetic resources for food and agriculture are covered by patents. Unfortunately there is no evidence in Australia to address this issue, although there is experience in other related commercial endeavours in Australia where patents have deterred further innovation, 111 and some evidence that restricting patent scope may promote incremental, or follow-on innovation, that is beneficial for second-order economies like Australia. ${ }^{112}$ Further there have been very limited policy analyses of the potential benefits of maintaining a distinction between the subject matter of patents and $\mathrm{PBR}^{113}$ and ensuring access to the plant genetic resources for food and agriculture necessary for incremental plant breeding to meet Australia's particular circumstances. ${ }^{114}$ The analysis of patent grants and PBR registrations in Australia by non-residents compared with Australia's major export destinations (see Table 5) also suggests Australia's interests might not favour strong patent and PBR rights unless there is proper disclosure through an adequate description and access to the necessary know-how to work the protected materials and processes to use those materials, and the patented technology does in practice improve agricultural efficiency and competitiveness. Without further analysis, the apparent assumption of Australia's negotiators of overall benefit from the intellectual property provisions in the PGRFA Treaty, and Australia's

111 See, eg, Genentech's withdrawal from research into erythropoietin once the gene patent had been granted to Amgen: see Lawson and Pickering, 'Patenting Genetic Material', above n 57, 76 .

112 See Ted O'Donoghue, Suzanne Scotchmer' and Jacques-François Thisse, 'Patent Breadth, Patent Life, and the Pace of Technological Progress' (1998) 7 Joumal of Economics and Management Strategy 1; Suzanne Scotchmer and Jerry Green, 'Novelty and Disclosure in Patent Law' (1990) 21 RAND Joumal of Economics 131; Intellectual Property and Competition Review Committee, Reoiew of Intellectual Property Legislation Under the Competition Principles Agreement (2000) 138-9; further, the Industry Commission concluded empirical data from Australia and overseas showed patents had limited commercial importance, had limited effectiveness, delayed imitation, failed to provide adequate disclosure and that innovation spill over was limited: see Nicholas Gruen, Ian Bruce and Gerard Prior, 'Extending Patent Life: Is it in Australia's Economic Interests?' (Staff Information Paper, Industry Commission, 1996).

113 For examples, the Rural Industries Research and Development Corporation deals with PBR as if they were the same as patents and attempts no separate analysis: John Asker and Andrew Stoeckel, 'Intellectual Property in Agricultural Trade' (Rural Industries Research and Development Corporation, 1999); the House of Representatives Standing Committee on Primary Industries and Regional Services, Parliament of Australia, Work in Progress: Proceed with Caution - Inquiry into Primary Producer Access to Gene Technology (2000), said in considering patents and plant breeder's rights over genetically modified organisms 'it would not be in the interests of Australian agriculture overall to change the current arrangements' (at 114), although there was no analysis of the interaction between patents and plant breeder's rights and the reasons for this conclusion were not presented.

114 A notable exception has been the Expert Panel on Breeding, Clarification of Plant Breeding Issues Under the Plant Breeder's Rights Act 1994 (2002) 26-8, although this analysis was brief and inconclusive: '[t]he effect of the [Plant Breeder's Rights Act] should be to encourage breeders and biotechnologists to work cooperatively to [their] mutual benefit, and should not alienate the parties by polarising their efforts': at 28 . 
adoption of the same stance as first-order developed countries, is open to question. This stance is also reflected in Australia's participation in the COP to the CBD and their implementations of the CBD's access requirements. 115 However, there is sufficient evidence available to suggest that the assumed benefits of plant and plant variety patenting may be interfering with plant breeding to warrant further policy analysis. 116 For example, an informal survey of public plant breeders in the United States showed significant difficulty in obtaining genetic stocks from private companies, impeded research, impeded release of new plant varieties and impeded student training, ${ }^{117}$ and an econometric analysis of United States PBR legislation concluded the statutory rights served primarily as a marketing tool with little impact on excludability or appropriability, with no increase in private sector investment and no increase in experimental or commercial yields. ${ }^{118}$ Australia's PGRFA Treaty stance might in fact lead to unnecessary costs on Australian agriculture and the failure to generate useful new varieties suited to Australia and its particular agricultural landscape. 119

Perhaps, most importantly, Australia's future agricultural landscape requires access to plant genetic resources for food and agriculture including both inter-specific and intra-specific species diversity, ${ }^{120}$ and the genetic diversity that may be accessed using modern genetic techniques. ${ }^{121}$ These useful resources might be categorised for the purposes of crop and forage plant improvement by the techniques used to exploit the diversity:

(a) Modern genetic (or molecular biology) techniques - where there is the introduction of new genetic materials (from all sources) into an existing crop or forage plant variety. ${ }^{122}$ This variety has often been classically (or conventionally)

115 For an analysis and criticism of Australia's implementation of the CBD's access scheme in the Environmental Protection and Biodiversity Conseroation Act 1999 (Cth) s 301 see Lawson and Downing, above $\mathrm{n}$ 50, 228-30.

116 For analyses of the patenting activity in key crops in the United States see Peter Philips and Dan Dierker, 'Public Good and Private Greed: Realising Public Benefits from Privatised Global Agrifood Research' in Philip Pardey (ed), The Future of Food: Biotechnology Markets

117 and Policies in an International Setting (2001) 129, 131.

118 Julian Alston and Raymond Venner, 'The Effects of the US Plant Variety Protection Act, on Wheat Genetic Improvement' (EPTD Discussion Paper No 62, International Food Policy Research Institute, 2000); see also Rangnekar, above n 6, 9-12; for a contrasting view see Greg Traxler, 'Balancing Basic Genetic Enhancement and Cultivar Development Research in an Evolving US Plant Germplasm System' (1999) 2 AgBio Forum 43, although this latter paper, like many others promoting the benefits of plant intellectual property rights, fails to provide empirical data or analysis in support of its assertions.

119 See, eg, the critique of James Boyle, Shamans, Software and Spleens - Law and the Construction of the Information Society (1996) 197: '[t]he blandishments of the international information industries notwithstanding, more intellectual property rights may actually mean less innovation, less heterogeneity in culture and environment and a less informed world of public debate' (emphasis in original).

120 See Food and Agriculture Organization of the United Nations, The State of the World's Plant Genetic Resources for Food and Agriculture (1998) ch 1.

121 See, eg, Gordon Conway and Gary Toenniessen, 'Feeding the World in the Twenty-First Century' (1999) 402 Nature C55.

122 Current plant transformation techniques always introduce genetic material, although in future, techniques such as homologous allelic recombination should enable the 
bred for desirable traits that are not presently susceptible to modern genetic techniques, such as increasing water use efficiency. This may also include the introduction of a desirable trait into crop and forage plants using modern genetic techniques followed by classical breeding techniques to exchange the introduced material into other (more favourable) background germplasms; and

(b) Classical (or conventional) breeding techniques ${ }^{123}$ - where there is genetic exchange between the germplasm (including the entire plant genome) of true biological species including all cultivated, wild and weedy forms of the crop and forage plant species. Hybrids are selected for desirable inherited traits that are often uncharacterised gene complexes that are not presently amenable to modern genetic techniques. While modern genetic techniques in this context are not used to exchange genetic materials, these techniques can assist in identifying and selecting desirable inherited traits (sometimes called assisted classical (or conventional) breeding).

These useful plant genetic resources for food and agriculture reside in existing ex situ collections, where much of the elite germplasm of commercially valuable crop and forage plants has already been identified and enhanced for favourable characteristics through classical breeding techniques, and in the in situ high level intra-specific diversity that is predominantly maintained by farmers continuing to crop broadranging germplasm in developing countries. ${ }^{124}$ Modern genetic techniques are also likely to be applied to these plant genetic resources for food and agriculture to reduce input agricultural costs (such as herbicide resistance, and so on) and confer specific desirable characters for high value markets (such as extended shelf-life, and so on). Put another way, the landscape is likely to require:

(a) Bulk commodity crops that compete in the international arena on price - where developing plant varieties with increased yield (including maintaining yields in adverse environments, such as salt-degraded farm lands) and reduced input costs (such as pesticide and herbicide resistance) will depend on access to plant

replacement of genetic materials: see for a discussion Richard Jefferson, 'Transcending Transgenics: Are There "Babies in the Bathwater" or is That a Dorsal Fin?" in Philip Pardey (ed), The Future of Food: Biotechnology Markets and Policies in an International Setting (2001) 75, 83-6.

123 See Clive Stannard, 'Genetic Resources: Adding Value or Biopiracy?' (Paper presented at the WIPO Conference on the International Patent System, Geneva, 25-7 March 2002): Classical plant breeding involves the incremental improvement of crop varieties. It is employed at intra-specific level, not at species level, and crosses and selects from a very wide range of varieties to create an improved genome. Characteristically, some tens of parent varieties are involved, over many years, each of which is itself the result of earlier generations of formal or informal breeding, and which already share most of their genomes. The product is again a variety, either released without intellectual property protection by the public sector, or when produced in the private sector, most frequently released under plant varietal protection (such as the UPOV system), where the object of protection is the variety, not the gene, and where, in fact, the so-called 'breeder's exemption' allows anyone - farmer or breeder - to use the genes within a protected variety. Individual resources infrequently provide largescale appropriable benefits.

124 See, eg, National Interest Analysis, above n 2, [5]-[8]. 
genetic resources for food and agriculture to suit Australia's particular environment;

(b) Niche crops that compete on distinctiveness and quality - where developing new varieties (often minor crops targeted to identifiable high-value markets) will depend on access to plant genetic resources for food and agriculture that exhibits diversity and market specific characteristics (such as colour, smell, exoticness, and so on); and

(c) Forage plants suited to Australia's agro-ecological zones - where developing improved forages that deal specifically with Australia's climate extremes, poor and degraded soils and pests will require access to plant genetic resources for food and agriculture to suit Australia's particular environment.

The challenge for Australia in negotiating intellectual property measures in agreements is to achieve an internationally agreed outcome that ensures access to these key genetic resources for food and agriculture. The options at their most basic are now:

(a) The CBD has established an internationally agreed scheme, to which Australia is already bound, for access to all genetic resources except that some significant $e x$ situ collections made before 29 December 1993 are excluded; and

(b) The PGRFA Treaty proposes to modify this scheme directed to particular plant genetic resources for food and agriculture and includes some significant $e x$ situ collections made before 29 December 1993

The key issues are to determine whether a separate access scheme proposed by the PGRFA Treaty is beneficial to Australia and then whether Australia's best interests are in negotiating intellectual property restrictions on access to the plant genetic resources for food and agriculture within the Multilateral System. There seems little doubt that the PGRFA Treaty is beneficial. It provides a simple and guaranteed scheme to access important $e x$ situ collections (such as the CGIAR collections and their elite germplasm stocks) and other important in situ resources without the unregulated commercial negotiation, or complex regulation provided for in the CBD. This is likely to assist countries like Australia to avoid many of the negotiation complexes over privately appropriated plant genetic resources for food and agriculture held by non-residents. However, the likely benefit from Australia's stance in the negotiated intellectual property provisions is unclear, and has the potential to impose significant costs on Australian agriculture in the future.

As a result of the intellectual property provisions presently favoured by Australia, much of the useful plant genetic resources for food and agriculture that would have been freely available is likely to be subject to broadly claimed patents and PBRs held by non-residents and no longer freely available. The stark effect of the patent's and PBR's 'exclusive rights' is to remove that material from the public domain and so from the PGRFA Treaty's Multilateral System, for the term of the patent or PBR with very minimal changes. For PBRs this is ameliorated to some extent by an experimental use and breeding new variety exemptions. ${ }^{125}$ These 'exclusive rights', and in particular the patent's 'exclusive rights', have significant consequences for Australia as the possible market failure for Australia's agricultural future is that private firms in the first-order developed countries (in particular the United States, see Tables 3-6) will seek to commercialise their protected developed plants and plant varieties with minimal

125 Plant Breeder's Rights Act 1994 (Cth) s 16(b), (c). 
changes and broad claims. This is likely to prevent or impede (through commercial barriers such as high costs, refusals to supply, and so on) the essential use and development of plant genetic resources for food and agriculture that are best suited to Australia's commercial interests and environment. Further, potential contributors of new plant genetic resources for food and agriculture to the Multilateral System are unlikely to have confidence in a scheme that appropriates their resources. ${ }^{126}$ If these analyses are correct, then Australia's stance in negotiating the implementation of the PGRFA Treaty is probably best served by seeking to make the plant genetic resources for food and agriculture accessed from the Multilateral System, and subsequent developments of those materials, continue to be freely available. In other words, Australia should seek to keep plant genetic resources for food and agriculture accessed from the Multilateral System and subsequent improvements of those materials free from the privately appropriating effects of the patent's and PBR's 'exclusive rights' Without this access, in second-order economies like Australia, where the majority of technology is imported, this is likely to undermine the needs of competitors and technology users ${ }^{127}$ and promote under-investment in necessary innovation to suit Australia's particular commercial and environmental circumstances. ${ }^{128}$

126 This has already surfaced as a problem and accounts for the reluctance of some Contracting Parties to include certain plant genetic resources for food and agriculture within the Annex 1 list (see Table 1), and as a consequence these materials were included in negotiations but left off the list (see Table 2): see CGRFA-Ex 6/01/REP, above $n 34$.

127 See, eg, Maskus, above n 99, 238.

128 See generally Per Pinstrup-Andersen and Marc Cohen, 'Achieving Sustainable Food Security for All: The Role of Policy, Global Public Goods, Property Rights, and Collective Action' in Japan Bank for International Cooperation, Deoelopment Assistance Strategies in the 21st Century: Global and Regional Issues (JBIC Research Paper No 16, July 2002) vol 1, 57. 